\title{
Employee Stock Options And Diluted Earnings Per Share: An Extension
}

David T. Doran, (Email: dtd1@psu.edu), Penn State, Erie

\begin{abstract}
Firms must currently apply the fair value method in determining the amount of employee compensation incurred in the case of employee stock options. The amount of such compensation is required to be measured as fair value of the equity instrument at the grant date, with compensation expense recognized over the service period under the straight-line method. This compensation expense affects the numerator for purposes of calculating earnings per share (EPS) under generally accepted accounting principles (GAAP). Current GAAP also requires that for purposes of calculating diluted EPS, the treasury stock method be applied where the assumed proceeds from exercise of the optioned shares is used to purchase shares of the firm's stock at its average market price of the earnings period. These incremental shares increase the denominator for purposes of calculating diluted EPS. These requirements are consistent across the pronouncements of the Financial Accounting Standards Board (FASB) and the International Accounting Standards Board (IASB). This study extends the work of Doran (2005) where a single period model was assumed and found: 1. Application of the fair value method does not double count the impact of compensation recognized, and 2. Applying the treasury stock method where shares are assumed purchased at the average for the period price (instead of end of year price) understates the number of incremental shares (the denominator), which overstates diluted EPS. This paper employs a simple multi period model that assumes a risk free environment with complete certainty in testing the accuracy of GAAP compliant diluted EPS in the case of employee stock options. Consistent with Doran (2005) the results here again indicate that assuming purchase of treasury shares at their average market price of the earnings period understates the EPS denominator. The results of this study also indicate that the reported employee compensation expense is understated. The observed cause of this numerator error is treating the "payment" for the option (employee service) as if it was received in full at the grant date - as a lump sum (like inventory or some other asset), rather than being received ratably over the employee service period - as an annuity. Each of these findings contributes to the observed overstatement of diluted EPS. Correct diluted EPS is observed when the employee service is treated as being received ratably over the service period, and the shares assumed purchased as treasury stock are acquired at the higher period ending market price. The amount of diluted EPS overstatement under both FASB and IASB standards is directly related to the length of the term of the option.
\end{abstract}

\section{BACKGROUND}

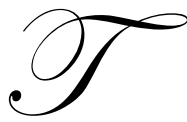

he Financial Accounting Standards Board (FASB) issued a revised Statement No. 123 (SFAS No. 123R) in December 2004 that requires the fair value method of accounting for employee stock options. The International Accounting Standards Board (IASB) likewise requires the fair value method in International Financial Reporting Standard (IFRS) No. 2. These standards are uniform in mandating that this "fair value" amount is measured with reference to the instrument granted and disallows using the value of employee services received. Explaining their position the IASB states, "Because of the difficulty of measuring directly the value of services received, the entity shall measure the fair value of the services received by reference to 
the fair value of the equity instruments granted....". The FASB using similar language states, "A share based payment transaction with employees shall be based upon the fair value .... of the equity instruments issued". ${ }^{2}$

In the case of outstanding stock options, diluted earnings per share must include incremental shares determined under the treasury stock method. This method assumes all options are exercised at the beginning of the period (or date of grant if issued during the period). The proceeds from this assumed issuance are used to purchase shares of the firm's stock for the treasury. If the option price is less than the reacquisition price, more shares will be assumed issued than are assumed purchased for the treasury. This difference represents "incremental shares" that are added to the denominator of the EPS calculation with a resulting dilution. Previously under US GAAP, the number of incremental shares was determined under APB No. 15, but was superceded by SFAS No. 128 which states: "The Board made one change to the treasury stock method prescribed in Opinion 15. This Statement requires that the average stock price for the period always be used in determining the number of treasury shares assumed purchased with the proceeds from the exercise of options or warrants rather than the higher of the average or ending stock price as prescribed by Opinion 15. The Board believes that use of the average stock price is consistent with the objective of diluted EPS to measure earnings per share for the period based on period information and that use of end-ofperiod data or estimates of the future is inconsistent with that objective. If purchases of treasury shares actually were to occur, the shares would be purchased at various prices, not at the price at the end of the period. In addition, use of an average stock price eliminates the concern that end-of-period fluctuations in stock prices could have an undue effect on diluted EPS if an end-of-period stock price were required to be used." ${ }^{3}$ The IASB also requires that the number of incremental shares be calculated by assuming purchase at average for the period price, "The difference between the number of ordinary shares issued and the number of ordinary shares that would have been issued at the average market price of ordinary shares during the period shall be treated as an issue of shares for no consideration". ${ }^{4}$

\section{PURPOSE OF STUDY AND METHODOLOGY}

This study extends the effort of Doran (2005) that incorporated a single period model that tested the accuracy of diluted EPS in the case of employee stock options. Doran (2005) found: 1. Application of the intrinsic value method does not adequately recognize the impact of employee compensation, and the fair value method is needed, and 2. Applying the treasury stock method where shares are assumed purchased at the average for the period price (instead of end of year price) understates the number of incremental shares (the denominator), which overstates diluted EPS. Applying the intrinsic value method caused "material"5 EPS misstatements, whereas assuming treasury shares were purchased at the average for the period price did not. This study extends the work of Doran (2005) by analyzing EPS accuracy in accounting for employee stock options while incorporating a multi-period model.

A simple multi-period model that assumes complete certainty is developed. The fair value of employee compensation is given, and the complete certainty assumption indicates that the employee and the firm should be economically indifferent to various compensation schemes (cash transfer, debt issue, stock transfer, or stock option grant). Given this economic equivalence, the true amount of EPS is "known" and should be consistently observed regardless of the compensation scheme assumed. Initially EPS is calculated under the cash, debt issue, and stock transfer scenarios. For each of these scenarios, calculated EPS amounts are found to equal the "known" EPS. This indicates that GAAP is appropriate in accounting for cash, debt, and stock transfers. Diluted EPS is then calculated assuming the stock option scenario. If current GAAP is appropriate, EPS observed in the case of the stock option scenario should equal the "known" (correct) amounts. The fair value method is applied and any treasury stock is assumed acquired at the average for the period price. The results indicate observed EPS is misstated by understating the amount of employee compensation expense and assuming too many shares are purchased for the treasury. This

\footnotetext{
${ }^{1}$ International Financial Reporting Standard No. 2, (2006) Paragraph 11.

${ }^{2}$ Statement of Financial Accounting Standards No. 123, Revised (December 2004) Paragraph 7.

${ }^{3}$ Statement of Financial Accounting Standards No. 128 (February 1997) Paragraph 107.

${ }^{4}$ International Accounting Standard No. 33, (2006) Paragraph 45.

${ }^{5}$ Although no longer authoritative, APB No. 15 identified $3 \%$ as the materiality threshold for earnings overstatement by then mandating the presentation of "fully diluted" EPS in addition to the presentation of "primary" EPS.
} 
combination results in an overstatement of the EPS numerator and an understatement of the EPS denominator, both of which contribute to overstatement of EPS when accounting for employee stock options under GAAP.

\section{MODEL}

The analysis is based upon various compensation schemes by a firm for an employee who renders services to the firm worth $\$ 1$ million at the beginning of each of four consecutive years. This simple four period model includes the following assumptions:

1. There is no risk, and all entities earn an available $10 \%$ risk free rate of return.

2. There are no dividends, taxes, or transaction costs.

3. The book value of the firm is $\$ 220$ million at $1 / 1 / 1$.

4. The firm has 10 million shares of stock outstanding at $1 / 1 / 1$ and the market value per share is $\$ 22$, the total market value of the firm is $\$ 220$ million.

5. If a stock option is used as compensation, it vests immediately, is fully transferable, and if employee terminates employment prior to the 4 year option term, s(he) must exercise immediately.

The FASB indicates that firms generally set the option price at least at the stock's market value on the grant date, and in doing so avoid creating any intrinsic value. This minimum option price would result in granting an option to buy $500 \mathrm{k}$ shares at $\$ 22$ per share.

Under the assumptions of the model, all participants are certain that the market value of the stock in one year (1/1/2) will be $\$ 24.20$ per share, $\$ 26.62$ on $1 / 1 / 3$, and $\$ 29.282$ on $1 / 1 / 4$. With that being the case, the employee and the firm should be indifferent between compensation packages of:

a. Compensation of $\$ 1$ million cash paid on $1 / 1 / 1,1 / 1 / 2,1 / 1 / 3$, and $1 / 1 / 4$,

b. Issuing $\$ 1$ million $10 \%$ notes on $1 / 1 / 1,1 / 1 / 2,1 / 1 / 3$, and $1 / 1 / 4$,

c. Transferring 45,454.54.... shares of stock on 1/1/1 (@ $\$ 22 / \mathrm{sh}=\$ 1,000,000), 41,322.31 \ldots$ shares of stock on 1/1/2 (@ \$24.20/sh=\$1,000,000),37,565.74.... shares of stock on 1/1/3 (@ \$26.62/sh=\$1,000,000), and 34,150.67.... shares of stock on 1/1/4 (@29.282/sh=\$1,000,000), or

d. Granting the employee an option to purchase 500,000 shares of the firm's stock for $\$ 22.00$ per share for a term of 4 years (see assumption 5 above).

Given the economic equivalence of the cash payment vs. debt issue vs. stock transfer vs. stock option compensation scenarios, the computed earnings per share should be consistent across these alternatives. Computed EPS should increase by ten percent per year and these known amounts are: $\$ 2.20$ for $01, \$ 2.42$ for $02, \$ 2.662$ for 03 and $\$ 2.9282$ for 04 .

\section{RESULTS}

Table one provides the GAAP based calculation of EPS in the case of cash compensation (Panel A), debt issue (Panel B), and stock transfer (Panel C). They each provide the true "known" amounts of earnings per share. These are the correct performance measures given the model assumptions of a requisite 10\% return and the 1/1/01 fair value of the stock of $\$ 22$ per share. Note that the income before compensation and interest expense is initially higher under the debt issue scenario than under the cash payment scenario. This is attributed to the additional cash ( $\$ 1$ million) being retained by the firm at the beginning of each year and invested to earn the risk free rate of $10 \%$. However, the recognition of interest expense results in these scenarios having the same net income measures. Net income is higher in the case of the stock transfer scenario. This is caused by the additional cash retention (consistent with the debt issue scenario), without reduction for interest expense. Note however that this numerator increase is offset by a proportionate denominator increase due to the issuance of shares, such that the "known" amount of EPS consistently results. 
Table 1

Diluted EPS Assuming: Cash, Debt, or Stock Issuance as Compensation

Panel A

Cash Compensation

\begin{tabular}{lccrc}
\hline & Year 1 & Year 2 & Year 3 & Year 4 \\
\hline $\begin{array}{l}\text { Income before } \\
\text { Compensation expense }\end{array}$ & $\$ 23,000,000$ & $\$ 25,200,000$ & $\$ 27,620,000$ & $\$ 30,282,000$ \\
\hline Comp. Exp. & $1,000,000$ & $1,000,000$ & $1,000,000$ & $1,000,000$ \\
Net Income & $\$ 22,000,000$ & $\$ 24,200,000$ & $\$ 26,620,000$ & $\$ 29,282,000$ \\
& & & & \\
Shares outstanding & $10,000,000$ & $10,000,000$ & $10,000,000$ & $10,000,000$ \\
EPS & $\$ 2.20$ & $\$ 2.42$ & $\$ 2.662$ & $\$ 2.9282$ \\
\hline
\end{tabular}

Panel B

Debt Issuance Compensation

\begin{tabular}{lccrr}
\hline & Year 1 & Year 2 & Year 3 & Year 4 \\
\hline Income before Interest & & & & \\
Compensation expense & $\$ 23,100,000$ & $\$ 25,410,000$ & $\$ 27,951,000$ & $\$ 30,746,100$ \\
\hline Interest Exp. & 100,000 & 210,000 & 331,000 & 464,100 \\
\hline Compensation Exp. & $1,000,000$ & $1,000,000$ & $1,000,000$ & $1,000,000$ \\
Net Income & $\$ 22,000,000$ & $\$ 24,200,000$ & $\$ 26,620,000$ & $\$ 29,282,000$ \\
& & & & 1000 \\
Shares outstanding & $10,000,000$ & $10,000,000$ & $10,000,000$ & $10,000,000$ \\
EPS & $\$ 2.20$ & $\$ 2.42$ & $\$ 2.662$ & $\$ 2.9282$ \\
\hline
\end{tabular}

Panel C

Stock Issuance Compensation

\begin{tabular}{lccrr}
\hline & Year 1 & Year 2 & Year 3 & Year 4 \\
\hline Income before & & & & \\
Compensation expense & $\$ 23,100,000$ & $\$ 25,410,000$ & $\$ 27,951,000$ & $\$ 30,746,100$ \\
\hline Comp. exp. & $1,000,000$ & $1,000,000$ & $1,000,000$ & $1,000,000$ \\
Net Income & $\$ 22,100,000$ & $\$ 24,410,000$ & $\$ 26,951,000$ & $\$ 29,746,100$ \\
& & & & \\
Shares outstanding & $10,045,454.55$ & $10,086,776.86$ & $10,124,342.6$ & $10,158,493.27$ \\
EPS & $\$ 2.20$ & $\$ 2.42$ & $\$ 2.662$ & $\$ 2.9282$ \\
\hline
\end{tabular}

Table 2 (Panel A) illustrates diluted EPS under GAAP. With the assumptions of the model the fair value of the option is determined by ${ }^{6}$ :

$$
\mathrm{O}=\mathrm{M}-\mathrm{E} /(1+\mathrm{i})^{\mathrm{n}}
$$

Where: $\mathrm{O}=$ option value on grant date,

$\mathrm{M}=$ market price of stock on grant date $=\$ 22 /$ share,

$\mathrm{E}=$ exercise price $=\$ 22 /$ share,

$\mathrm{i}=$ risk free interest rate $=10 \%$, and

$\mathrm{n}=$ number of years until option expires $=4$ years.

\footnotetext{
${ }^{6}$ See Nikolai (2007) pg. 783
} 
Table 2

Diluted EPS Assuming Stock Option Compensation

Panel A

Stock Options Accounted for Under GAAP:

Employee Service Assumed Provided in Full at Grant Date, and Treasury Shares Purchased at Average Period Price

\begin{tabular}{lccrr}
\hline & Year 1 & Year 2 & Year 3 & Year 4 \\
\hline $\begin{array}{l}\text { Income before } \\
\text { Compensation expense }\end{array}$ & $\$ 23,100,000$ & $\$ 25,410,000$ & $\$ 27,951,000$ & $\$ 30,746,100$ \\
\hline Compensation expense & 871,713 & 871,713 & 871,713 & 871,713 \\
Net Income - Numerator & $\$ 22,228,287$ & $\$ 24,538,287$ & $\$ 27,079,287$ & $\$ 29,874,387$ \\
& & & & \\
Shares outstanding & $10,000,000$ & $10,000,000$ & $10,000,000$ & $10,000,000$ \\
Incremental shares & $23,809.52$ & $67,099.57$ & $106,454.15$ & $142,231.05$ \\
Denominator & $10,023,809.52$ & $10,067,099.57$ & $10,106,454.15$ & $10,142,231.05$ \\
& & & & $\$ 2.70793$ \\
EPS & $\$ 2.22283$ & $\$ 2.45383$ & $\$ 2.98744$ \\
\hline
\end{tabular}

Panel B

Stock Options Accounted for With:

Employee Service Assumed Provided Over Service Period, and Treasury Shares Purchased at End of Period Price

\begin{tabular}{lcccc}
\hline \multicolumn{1}{c}{ Year 1 } & Year 2 & Year 3 & \multicolumn{1}{c}{ Year 4 } \\
\hline Income before & & & & $\$ 30,746,100$ \\
\hline Compensation expense & $\$ 23,100,000$ & $\$ 25,410,000$ & $\$ 27,951,000$ & $1,000,000$ \\
Net Income - Numerator & $1,000,000$ & $1,000,000$ & $1,000,000$ & $\$ 29,746,100$ \\
& $\$ 22,100,000$ & $\$ 24,410,000$ & $\$ 26,951,000$ & $10,000,000$ \\
Shares outstanding & & & & $10,000,000$ \\
Incremental shares & $10,000,000$ & $10,000,000$ & $124,342.60$ & $158,493.27$ \\
Denominator & $45,454.55$ & $86,776.86$ & $10,124,342.60$ & $10,158,493.27$ \\
& $10,045,454.55$ & $10,086,776.86$ & & $\$ 2.9282$ \\
\hline
\end{tabular}

Solving the option pricing formula results in each option share valued at $\$ 6.9737 \ldots$. , and the entire 500,000 optioned shares valued at $\$ 3,486,852$. SFAS No. $123(\mathrm{R})$ and IFRS No. 2 require this estimated value of the equity instruments be used to value the transaction with compensation expense recognized on a straight-line basis over the service period. GAAP therefore requires recognizing $\$ 871,713$ of employee compensation expense in each of the four years. Since the worth of the employee compensation assumed in this model is known with certainty ( $\$ 1$ million per year), the amount of compensation expense recognized under GAAP is understated by $\$ 128,287$ each year ( $\$ 1$ million - \$871,713). The known amount of compensation expense can be calculated by treating the employee service appropriately. That is, the employee provides service ratably over the four years, not in full at the date of grant. To express it in a present value context, the employee pays for the equity instrument by providing service over time - like an annuity, rather than providing the service in full at the grant date - like a lump sum. Applying the assumptions of this model, the calculated amount of 4 annuity due payments discounted at $10 \%$ resulting in a present value of $\$ 3,486,852$ is $\$ 1$ million per year. This known amount is presented in Table 2 (Panel B) as the correct amount of employee compensation used for purposes of calculating diluted EPS.

Table 2 (Panel A) applies the treasury stock method required under GAAP. Consistent with SFAS No. 128 and IAS No. 33, the number of incremental treasury shares is determined using the average for the year market value of the stock. The average market value used is the arithmetic average of the beginning and ending values per share 
each year. For year 1, beginning and ending values are $\$ 22$ and $\$ 24.20$, respectively, which equals $\$ 23.10$ per share average market price. The average market price for years 2,3 , and four, respectively are $\$ 25.41, \$ 27.951$, and $\$ 30.7461$. Doran (2005) shows that under these simple model assumptions, the correct EPS amounts are derived when shares are assumed purchased for the treasury at the higher year-end market price. Table 2 (Panel B) applies the treasury stock method while assuming purchase at the year-end price.

The combination of treating the employee service as provided ratably over the service period (as an annuity), and assuming shares are purchased for the treasury at the higher year-end price results in the correct "known" amounts of diluted EPS - see Table 2 (Panel B).

\section{CONCLUSION}

As can be seen from Table 2 (Panel A), calculated EPS is consistently overstated under US and IASB standards. The known amounts of correct EPS are derived only when the employee service is appropriately treated as an annuity - assumed received over time, and the shares purchased for the treasury are assumed acquired at the higher year-end price. As can be seen from Table 2, the percentage error in EPS overstatement increases over the four-year period. The overstatement is $1.04 \%$ in year one but increases each year to $2.02 \%$ in year 4 . Since the overstatement of the numerator is a constant $(\$ 128,287$ per year) the increase in EPS overstatement over time must be due to the denominator, which is caused by assuming purchase of treasury shares at the average for the period price. This makes sense under this model's assumptions. When a constant positive return rate is assumed - the difference between average for the period and end of the period market value becomes larger with the passage of time. The dollar amount of the error in the numerator is a function of future value (annuity) vs. present value (the lump sum). All other things being equal, this error will increase with the length of the option term. In summary, both of these factors cause diluted EPS overstatement, and the overstatement is positively related to the option's term.

\section{FUTURE RESEARCH}

This study assumed no actual purchases of treasury stock during the option period. Justification for using the average for the period market price for purposes of calculating incremental shares is provided by the FASB in SFAS No. 128: "This Statement requires that the average stock price for the period always be used in determining the number of treasury shares assumed purchased with the proceeds from the exercise of options or warrants rather than the higher of the average or ending stock price as prescribed by Opinion 15. The Board believes that use of the average stock price is consistent with the objective of diluted EPS to measure earnings per share for the period based on period information and that use of end-of-period data or estimates of the future is inconsistent with that objective. If purchases of treasury shares actually were to occur, the shares would be purchased at various prices, not at the price at the end of the period". ${ }^{7}$

Future research could be conducted that expands upon this effort by assuming the option granting firm purchases shares of its own stock for the treasury during the option term to determine if such purchases impact the observed diluted EPS overstatements.

\section{REFERENCES}

1. Accounting Principles Board, Opinion No. 15, Earnings per Share, May 1969.

2. Accounting Principles Board, Opinion No. 25, Accounting for Stock Issued to Employees, October 1972.

3. Doran, D.T., Employee Stock Options and Diluted EPS, Journal of Business and Economics Research, Vol. 3, No. 11, pp 51-56.

4. Financial Accounting Standards Board, Statement of Financial Accounting Standards No. 123, Accounting for Share-Based Compensation, October 1995.

\footnotetext{
${ }^{7}$ Statement of Financial Accounting Standards No. 128 (February 1997) Paragraph 107.
} 
5. Financial Accounting Standards Board, Statement of Financial Accounting Standards No. 128, Earnings per Share, February 1997.

6. Financial Accounting Standards Board, Statement of Financial Accounting Standards No. 123 (revised 2004), Share-Based Payment, December 2004.

7. International Accounting Standards Board, International Financial Reporting Standard No. 2, Share Based Payment, The full text of all International Financial Reporting Standards extant at January 1, 2006.

8. International Accounting Standards Committee, International Accounting Standard No. 33, Earnings per Share, The full text of all International Financial Reporting Standards extant at January 1, 2006.

9. Nikolai, Bazley, and Jones, Intermediate Accounting, 10 $0^{\text {th }}$ ed., Thomson South-Western, 2007.

\section{NOTES}


NOTES 